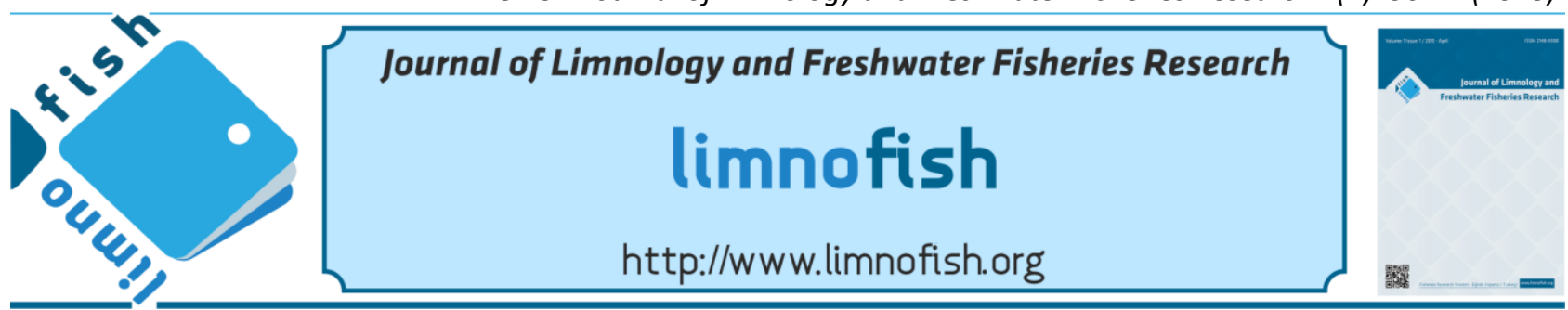

\title{
Immunostimulant Effects of Geophyte Plant Extract on Non-specific Defence Mechanisms of Rainbow Trout (Oncorhynchus mykiss)
}

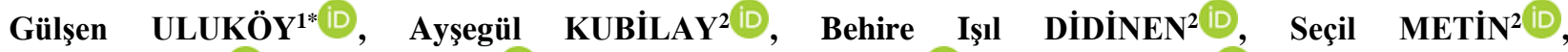

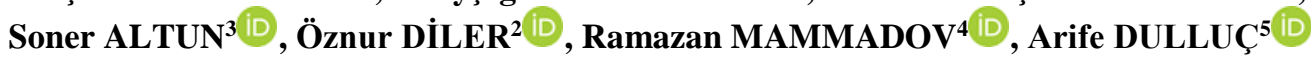 \\ ${ }^{1}$ Muğla Sttkı Kocman University Fisheries Faculty, Department of Aquaculture, 48000 Muğla-Turkey \\ ${ }^{2}$ Suleyman Demirel University Egirdir Fisheries Faculty, Department of Aquaculture, 32000 Isparta-Turkey \\ ${ }^{3}$ Uludağ University, Veterinary Faculty, 16059 Bursa-Turkey \\ ${ }^{4}$ Pamukkale University, Faculty of Arts and Sciences, Department of Biological Sciences 20000 Denizli-Turkey \\ ${ }^{5}$ Isparta Directorate of Provincial Food Agriculture and Livestock 32200 Isparta-Turkey
}

\section{A B STR ACT}

The aim of this study was to determine the immunostimulant effects of geophyte plant extract on non-specific defence mechanisms of rainbow trout (Oncorhynchus mykiss). For this purpose, Muscari comosum was collected in Muğla region and extracted in ethanol. Then, The plant extract applied into fish by intraperitonal injection in two different concentrations $(0.5 \mathrm{mg} /$ fish and 2.0 $\mathrm{mg} /$ fish). The average fish weight was $140 \mathrm{~g}$. Following the injection on the $1 \mathrm{st}$, 7th, 14th, 21st, 28th days the blood and serum samples were collected from fish in each group and examined for various parameters including percentage of hematocrit, the counts of nitroblue tetrazolium (NBT) positive neutrophils, total leukocyte counts, percentage of white blood cells and serum lysozyme activity. The results indicated that the counts of NBT (+) neutrophils, percentage of monocyte and neutophil and total leukocyte counts increased in the group with injected $0.5 \mathrm{mg}$ plant extract /fish compared to control group $(\mathrm{P}<0.05)$. It has been revealed that this dose of $M$. comosum can be suggested to use to enhance nonspecific immune system for rainbow trout aquaculture. However, immunostimulant effects of oral administration of this plant extract in rainbow trout are needed to be determine in future studies.

Keywords: Fish, immune system, Muscari comosum, Tassel hyacinth, blood
ARTICLE INFO

\section{RESEARCH ARTICLE}

Received : 09.01.2018

Revised : :07.03.2018

Accepted :09.03.2018

Published : 27.04.2018

DOI:10.17216/LimnoFish.376404

* CORRESPONDING AUTHOR

gulukoy@mu.edu.tr

Tel : +90252211 1519

Gökkuşağı Alabalığı (Oncorhynchus mykiss)’nın Spesifik Olmayan Savunma Mekanizması Üzerine Geofit Bitki Ekstraktının İmmunostimulant Etkisi

Öz: Bu çalışmada amacımız, gökkuşağı alabalığının spesifik olmayan savunma mekanizması üzerine geofit bitki ektraktının immunostimulant etkisinin belirlenmesidir. Bu amaçla geofit bir bitki olan M. comosum Muğla bölgesinden toplandı ve etanolde ekstrakte edildi. Daha sonra farklı dozlarında $(0,5 \mathrm{mg} / \mathrm{bal} 1 \mathrm{k}$ ve $2,0 \mathrm{mg} / \mathrm{bal}$ k) balıklara intraperitonal olarak uygulandı. Balıklar ortalama 140 g ağırlığa sahipti. Deneme süresince uygulamayı takiben $1,7,14,21,28$. günlerde herbir gruptaki balıktan kan ve serum örnekleri alınarak farklı parametreler (hematokrit yüzdesi, nitroblue tetrazolium (NBT) pozitif nötrofil sayısı, toplam lökosit sayısı, beyaz kan hücrelerinin yüzdesi ve serum lizozim aktivitesi) açısından incelendi. Bu çalışmanın sonucunda NBT pozitif nötrofillerin sayısı, monosit ve nötrofil yüzdeleri ve toplam lökosit sayısı $0,5 \mathrm{mg} / \mathrm{balık}$ dozunda injeksiyon yapılan grupta kontrol grubuna kıyasla artış gösterdiği $(\mathrm{P}<0,05)$ belirlendi. Bu nedenle gökkuşağı alabalığı yetiştiriciliğinde spesifik olmayan immun sistemi uyarmak için bu dozdaki M. comosum'un kullanılması önerilebilir. Ancak, bitki ekstraktının oral yolla yeme ilave edilerek balıklara uygulanması ile immunostimulant etkisinin belirlenmesi için gelecekte yeni çalışmalara ihtiyaç duyulmaktadır.

Anahtar kelimeler: Balık, immun sistem, Muscari comosum, arap sümbülü, kan

How To Cite

Uluköy G, Kubilay A, Didinen BI, Metin S, Altun S, Diler Ö, Mammadov R, Dulluç A, 2018. Immunostimulant Effects of Geophyte Plant Extract on Non-specific Defence Mechanisms of Rainbow Trout (Oncorhynchus mykiss). LimnoFish. 4(1): 36-41. doi: 10.17216/LimnoFish.376404

\section{Introduction}

Fish production has increased significantly over the past decades which has given rise to practices such as over crowding, transport, handling and grading in aquacultural systems. These practices are the major factors that make the fish susceptible 
against pathogens. Diseases are major constraints to aquaculture production (Plumb and Hanson 2011)

Fish disease is rarely a simple association between pathogen, a host fish and environmental problems, such as poor water quality or other stressors often contribute to the outbreak of disease. Fish disease, caused by pathogenic organisms present in the environment, they are mostly contagious and treatment may be necessary to control the disease outbreak. Therefore, intensive farming practices and infectious diseases induced major problems in aquaculture industry causing heavy loss to farmers. Several studies have been conducted on the modulation of fish immune system in order to prevent the outbreaks. Disease outbreaks are increasingly being recognized as a potential constraint on aquaculture production and trade and cause massive financial loss either through mortality or reduced meat quality, resulting in reduced profit margins (Plumb and Hanson 2011; Mehana et al. 2015).

The use of antibiotics and chemotherapeutics to combat fish diseases has the risk of generating resistant pathogens, bioaccumulation and environmental pollution. Commercial vaccines are expensive for fish farmers and are specific against particular pathogens (Christybapita et al. 2007). One of the most promising methods of controlling diseases in aquaculture is strengthening the defence mechanisms of fish through prophylactic administration of immunostimulants (Deivasigamani and Subramanian 2016; Christybapita et al. 2007). The different types of IS (e.g. glucan, chitin, lactoferrin, levamisole, vitamin B, C, E and growth hormone and prolactin) mainly facilitate the function of phagocytic cells. Several immunostimulants also stimulate the natural killer cells (NK), complement, lysozyme and antibody responses of fish (Dügenci et al. 2003; Mehana et al. 2015). Up to now, several plants which have been used as therapeutic in the control of pathogens which cause diseases in fish. (Awad and Awaad 2017). Geophyte plant, M. comosum (L.) Mill.1768, has medicinal properties (Villa et al. 2012; Nasrabadi et al. 2013) such as diuretic, anti-inflammatory, hypoglycemic activities (Loizzo et al. 2010) and antioxidant activity (Pieroni et al. 2002). Further, M. comosum had been determined immunustimulant effects on gilthead seabream (Sparus aurata) by Baba et al. (2014).

The aim of the present study was to determine the immunostimulant effects of $M$. comosum extract on the nonspecific immune responses of rainbow trout.

\section{Materials and Methods \\ Plant extraction}

The geophyte plant, Tassel hyacinth (Muscari comosum), was gathered from Muğla region of Turkey. Plant brought to laboratory for the extraction. Its bulbs were cleaned and chopped into small pieces (Lee et al. 2000; Tanker and Tanker 1991). The extraction process was continue in ethyl alcohol at $50^{\circ} \mathrm{C}$ in a water bath for $24 \mathrm{~h}$. The obtained solution was filtered and then remained mass was run again with applying same process as before. This step was repeated three times. The obtained extracts combined and lyophilized. The extract was stored in dark at $4^{\circ} \mathrm{C}$.

\section{Experimental design}

Healthy rainbow trout (mean weight of $140 \pm 10 \mathrm{~g}$ ) were taken from a private fish farm in Isparta and acclimated for 2 weeks and held in 600 liters tanks filled with freshwater at $12^{\circ} \mathrm{C}$, with a flow rate of 1-1.5 L min-1 with continuous aeration. Fish were fed with commercial pellets at $2 \%$ body weight and water quality parameters were monitored daily. The experimental fish were randomly divided into 3 groups, 50 fish/group in duplicate. The obtained lyophilized M.comosum extract was dissolved it in sterile phosphate-buffered saline (PBS) solution and then applied to fish with an intraperitoneal injection (i.p.) as $0.1 \mathrm{~mL}$ of two different concentrations as $0.5 \mathrm{mg} / \mathrm{fish}$ and $2 \mathrm{mg} / \mathrm{fish}$. The same volume of PBS i.p. injected into fish of control group.

\section{Sampling}

The each sampling day $\left(1^{\text {st }}, 7^{\text {th }}, 14^{\text {th }}, 21^{\text {st }}\right.$, and $28^{\text {th }}$ days), randomly selected total five fish from each group were taken and anesthetized by using phenoxyethanol. After anasthesizing fish, blood samples were drawn from the caudal vein and then fish sacrificed. A part of blood was put into an Eppendorf tube and then left at $4^{\circ} \mathrm{C}$ overnight and centrifuged at $3500 \mathrm{~g}$ for $15 \mathrm{~min}$ and then serum collected. The serum samples were stored at $-20^{\circ} \mathrm{C}$ until assayed.

\section{Determination of NBT-positive cells}

For the determination of the respiratory burst activity in the blood, Nitroblue tetrazolium (NBT) (Sigma No: N-6876) was used by following a modified method described by Anderson et al. (1992). A drop of blood placed onto a microscope coverslip and left in a petri dish which had humid atmosphere for $30 \mathrm{~min}$ at $25^{\circ} \mathrm{C}$. After incubation, the coverslip washed with 0.067 $\mathrm{mM}$ sodium phosphate buffer $(\mathrm{pH}$ 6.4) to remove unwanted cells and then a drop of $0.2 \%$ NBT solution 
(freshly prepared) was put on to slide and the coverslip with cells was turned cell face down on the NBT solution and incubated again in a petri dish for $30 \mathrm{~min}$ at $25^{\circ} \mathrm{C}$. The slides were examined under microscope (40x magnification). The dark blue staining cells were counted as positive. From each fish, five coverslips were prepared and five random microscopic fields were counted on each slide. Then the total twenty-five different fields were averaged and the mean and standard error of values per field for fish were calculated.

\section{Assay of lysozyme activity}

2 mg lyophilized Micrococcus lysodeikticus cells (Sigma, M 3770, ATCC No. 4698) was suspended with $10 \mathrm{ml} 0.05 \mathrm{M}$ sodium phosphate buffer (pH 6.5). The $3 \mathrm{ml}$ of from the solution was taken the spectrophotometer cells and than added onto $50 \mu 1$ fish serum. Following this process after 30 seconds and 4.5 minutes was performed two measurements with Shimadzu (UV-120-02) spectrophotometer at $540 \mathrm{~nm}$. One unit of lysozyme activity was defined as a reduction of absorbance of $0.001 / \mathrm{min}$ (Engstad et al. 1992).

\section{Counting of total leukocyte}

In the blood samples, the total leukocyte were counted from sampled fish. For this purpose, a Neubauer counting chamber was used and method was followed according to by Schaperclaus et al. (1991). After collection of blood from fish, the certain amount of blood was combined with NattHerrick solution in a leukocyte pipe. The leukocytes were counted in duplicate samples twice from each fish.

\section{Differential leukocyte count}

The method of Steinhagen et al. (1990) and Schaperclaus et al. (1991) were followed with slight modification to obtain the percentage of cell types of leukocytes. The double stains; May-Grunwald and Giemsa were used to stain of the prepared blood smears. These staining procedure provided that the specific types of the leukocytes was seen under the light microscope. A total of 100 leukocytes in each slide were counted by using a Neubauer chamber. The percentage of the cell types were calculated.

\section{Hematocrit level}

During the sampling days, blood samples were collected from fish by using heparinized capillary tubes. From each fish, two heparinized capillary tubes full with blood were obtained. Then, the hematocrit centrifuge (worked at $10,500 \mathrm{~g}$ for $5 \mathrm{~min}$ ) was used to read the hematocrit level of sampled blood. By following Steinhagen et al. 1990 and
Schaperclaus et al. 1991, the percentage hematocrit value of blood samples was determined by using a special scale.

\section{Statistics}

All data were analyzed by one-way analysis of variance using the general linear model. Duncan's Multiple Range test was used to compare treatment means. Differrences were considered significant at the 0.05 probability level. All analysis was performed using the SPSS program.

\section{Results}

It has been suggested that hematological parameters are useful indicators for monitoring fish health and especially immune response. In this study, the mean number of NBT-positive cells in a microscopic field was presented in Table1. NBTpositive cells in the fish group which received $0.5 \mathrm{mg}$ M. comosum were significantly increased $(\mathrm{P}<0.05)$ from the other groups on 21 and 28th days. This showed that giving dose increased phagocytic activity of neutrophils.

Total leukocyte counts in $M$. comosum $(0.5 \mathrm{mg} / \mathrm{fish})$ were determined significantly higher than other groups in 1 and 7 th days $(\mathrm{P}<0.05)$ (Table 1). While the first day after injection total leukocyte count was $0.69 \times 10^{5} / \mu 1$ in control group fish blood, $0.5 \mathrm{mg} /$ fish plant extract received fish groups showed highest cell count in $1 \mathrm{st}$ $\left(1.26 \times 10^{5} / \mu 1\right)$ and 7 th days $\left(1.14 \times 10^{5} / \mu 1\right)$. The other samplings days the high values seen in the plant extract received fish groups compare to control group.

The percentage of neutrophils and monocytes also significantly $(\mathrm{P}<0.05)$ increased in blood of the $0.5 \mathrm{mg} /$ fish plant extract received fish group (Table 2) compare to control and other group. The highest values of neutrophils and monocytes percentage were obtained in $0.5 \mathrm{mg} /$ fish plant extract received fish group in each sampling days (Table 2). The following group of high values was determined on percentage of neutrophils and monocytes in blood of $2 \mathrm{mg} / \mathrm{fish}$ plant extract received fish group. The different concentration of plant extract injected fish groups expressed stimulated activity on neutrophils and monocyte cells.

The serum lysozyme activities values was highest levels at the $21 \mathrm{st}$ and $28 \mathrm{th}$ days in the $0.5 \mathrm{mg} / \mathrm{fish}$ plant extract received fish group hovewer, haematocrit levels in rainbow trout blood didn't change after injection of $M$. comosum geophyte plant $(\mathrm{P}>0.05)$ into all fish groups.

Our results revealed that, M.comosum stimulated nonspecific immune parameters in rainbow trout. 
Table 1. Serum lysozyme activity (unit/ml), Hematocrit Level (\%), NBT(+) neutrophil counts/microscopic field,Total leukocyte counts $\left(\times 10^{5} / \mu \mathrm{l}\right)$ in fish blood after i.p. injection of geophyte plant extract.

\begin{tabular}{cccccc}
\hline \multirow{2}{*}{ Days } & Groups & $\begin{array}{c}\text { Serum lysozyme activity } \\
(\text { unit } / \mathrm{ml})\end{array}$ & $\begin{array}{c}\text { Hematocrit level } \\
(\%)\end{array}$ & $\begin{array}{c}\text { NBT(+) } \\
\text { Neutrophil counts }\end{array}$ & $\begin{array}{c}\text { Total leukocyte counts } \\
\left(\mathrm{x} 10^{5} / \mu \mathrm{l}\right)\end{array}$ \\
\hline \multirow{2}{*}{1} & $0.5 \mathrm{mg}$ & $55.25 \pm 25.16^{\mathrm{a}}$ & $38.87 \pm 4.09^{\mathrm{ab}}$ & $12.29 \pm 7.67^{\mathrm{bc}}$ & $1.26 \pm 0.24^{\mathrm{f}}$ \\
& $2 \mathrm{mg}$ & $146.66 \pm 98.65^{\mathrm{abcd}}$ & $37.21 \pm 5.36^{\mathrm{ab}}$ & $15.13 \pm 8.63^{\mathrm{c}}$ & $0.76 \pm 0.17^{\mathrm{bcd}}$ \\
& control & $180 \pm 67.33^{\mathrm{abcd}}$ & $39.76 \pm 5.03^{\mathrm{ab}}$ & $4.24 \pm 3.37^{\mathrm{ab}}$ & $0.69 \pm 0.69^{\mathrm{bcd}}$ \\
& $0.5 \mathrm{mg}$ & $284 \pm 116.96^{\mathrm{d}}$ & $39.10 \pm 3.97^{\mathrm{ab}}$ & $4.61 \pm 4.18^{\mathrm{ab}}$ & $1.14 \pm 0.22^{\mathrm{ef}}$ \\
7 & $2 \mathrm{mg}$ & $228 \pm 164.07^{\mathrm{cd}}$ & $41.05 \pm 2.57^{\mathrm{ab}}$ & $3.21 \pm 1.32^{\mathrm{ab}}$ & $0.70 \pm 0.14^{\mathrm{bcd}}$ \\
& control & $144 \pm 62.18^{\mathrm{abcd}}$ & $37.19 \pm 3.84^{\mathrm{ab}}$ & $3.38 \pm 1.95^{\mathrm{ab}}$ & $0.78 \pm 0.78^{\mathrm{bcd}}$ \\
& $0.5 \mathrm{mg}$ & $60 \pm 43.20^{\mathrm{a}}$ & $35.49 \pm 6.25^{\mathrm{a}}$ & $2.63 \pm 1.89^{\mathrm{a}}$ & $0.64 \pm 0.13^{\mathrm{abc}}$ \\
& $2 \mathrm{mg}$ & $110 \pm 62.18^{\mathrm{abc}}$ & $39.64 \pm 5.70^{\mathrm{ab}}$ & $2.34 \pm 1.64^{\mathrm{a}}$ & $0.66 \pm 0.12^{\mathrm{abcd}}$ \\
& control & $125 \pm 66.08^{\mathrm{abc}}$ & $36.04 \pm 5.23^{\mathrm{a}}$ & $2.42 \pm 1.94^{\mathrm{a}}$ & $0.66 \pm 0.15^{\mathrm{abcd}}$ \\
& $0.5 \mathrm{mg}$ & $195 \pm 99.83^{\mathrm{abcd}}$ & $39.30 \pm 3.49^{\mathrm{ab}}$ & $14.53 \pm 12.88^{\mathrm{c}}$ & $0.54 \pm 0.05^{\mathrm{ab}}$ \\
21 & $2 \mathrm{mg}$ & $220 \pm 160^{\mathrm{bcd}}$ & $43.13 \pm 2.82^{\mathrm{b}}$ & $2.82 \pm 1.16^{\mathrm{a}}$ & $0.81 \pm 0.16^{\mathrm{cd}}$
\end{tabular}

Data are represented as mean $\pm \mathrm{SE}(\mathrm{n}=10$ /group). Different letters represent the significant differences at $\mathrm{P}<0.05$

Table 2. The percentage of the leukocyte cells in fish blood after ip injection of geophyte plant extract.

\begin{tabular}{|c|c|c|c|c|}
\hline \multirow[b]{2}{*}{ Days } & \multirow[b]{2}{*}{ Groups } & \multicolumn{3}{|c|}{ Leukocytes Percentage (\%) } \\
\hline & & Lymphocyte & Monocyte & Neutrophil \\
\hline \multirow{3}{*}{1} & $0.5 \mathrm{mg}$ & $83.6 \pm 2.07^{\mathrm{bcd}}$ & $7.8 \pm 1.48^{\mathrm{b}}$ & $8.6 \pm 2.19^{\mathrm{abc}}$ \\
\hline & $2 \mathrm{mg}$ & $70.8 \pm 6.41^{\mathrm{a}}$ & $6.8 \pm 2.68^{b}$ & $22.4 \pm 5.36^{\mathrm{d}}$ \\
\hline & control & $87.2 \pm 3.11^{\text {bcde }}$ & $2 \pm 0.7^{\mathrm{a}}$ & $10.80 \pm 3.19^{\mathrm{bc}}$ \\
\hline \multirow{3}{*}{7} & $0.5 \mathrm{mg}$ & $82.80 \pm 3.11^{\mathrm{bcd}}$ & $11.6 \pm 2.19^{c}$ & $6 \pm 1.73^{\mathrm{ab}}$ \\
\hline & $2 \mathrm{mg}$ & $84 \pm 5.47^{\text {bcd }}$ & $7.2 \pm 3.11^{\mathrm{b}}$ & $8.8 \pm 2.68^{\mathrm{abc}}$ \\
\hline & control & $94.6 \pm 2.6^{\text {ef }}$ & $1.8 \pm 0.83^{\mathrm{a}}$ & $3.8 \pm 2.49^{\mathrm{a}}$ \\
\hline \multirow{3}{*}{14} & $0.5 \mathrm{mg}$ & $85.40 \pm 3.91^{\mathrm{bcd}}$ & $6.8 \pm 1.09^{\mathrm{b}}$ & $7.8 \pm 3.11^{\mathrm{abc}}$ \\
\hline & $2 \mathrm{mg}$ & $88.6 \pm 4.21^{\text {cdef }}$ & $3.8 \pm 1.64^{\mathrm{a}}$ & $7.6 \pm 3.13^{\mathrm{ab}}$ \\
\hline & control & $95 \pm 1.22^{\mathrm{ef}}$ & $1.8 \pm 0.44^{\mathrm{a}}$ & $3.4 \pm 0.54^{\mathrm{a}}$ \\
\hline \multirow[b]{2}{*}{21} & $0.5 \mathrm{mg}$ & $79.40 \pm 10.52^{\mathrm{b}}$ & $6.8 \pm 3.27^{\mathrm{b}}$ & $13.80 \pm 8.92^{c}$ \\
\hline & $2 \mathrm{mg}$ & $89.2 \pm 6.14^{\mathrm{def}}$ & $3.2 \pm 1.92^{\mathrm{a}}$ & $5.6 \pm 1.81^{\mathrm{ab}}$ \\
\hline \multirow{4}{*}{28} & control & $95.6 \pm 1.81^{\mathrm{f}}$ & $1.6 \pm 0.54^{\mathrm{a}}$ & $2.8 \pm 1.48^{\mathrm{a}}$ \\
\hline & $0.5 \mathrm{mg}$ & $70 \pm 5.61^{\mathrm{a}}$ & $7 \pm 2.44^{\mathrm{b}}$ & $23 \pm 2.44^{\mathrm{d}}$ \\
\hline & $2 \mathrm{mg}$ & $80.80 \pm 11.14^{\mathrm{bc}}$ & $3.2 \pm 1.92^{\mathrm{a}}$ & $10.2 \pm 7.52^{\mathrm{bc}}$ \\
\hline & control & $93.6 \pm 3.36^{\mathrm{ef}}$ & $1.5 \pm 0.57^{\mathrm{a}}$ & $3.4 \pm 1.67^{\mathrm{a}}$ \\
\hline
\end{tabular}

Data are represented as mean $\pm \mathrm{SE}(\mathrm{n}=10$ /group). Different letters represent the significant differences at $\mathrm{P}<0.05$ 


\section{Discussion}

Immunostimulants, influence growth performance and health condition in aquatic species by inducing a strong defence response against pathogens while minimizing the use of antibiotics. The immunostimulatory effects of plant extracts might vary by fish species, route of administration, dose, duration. Immunostimulants are critical in activate the immune responses capable of providing complete protection against certain pathogens.

The results of the present study indicate that there is a increasing number of NBT-positive cells after i.p.injection of $M$. comosum geophyte plant extract in rainbow trout $(0.5 \mathrm{mg} /$ fish). Similarly, there have also been reported related results in various fish species, such as in gilthead sea bream (Sparus aurata) for $M$. comosum (Baba et al. 2014); in tilapia Oreochromis mossambicus for leaf extracts of Ocimum sanctum (Logambal et al. 2000) and Tinospora cordifolia (Sudhakaran et al. 2006); in rohu (Labeo rohita) for Withania somnifera (Sharma et al. 2010); nile tilapia (Oreochromis niloticus) for Echinacea purpurea and Allium sativum (Aly and Mohamed 2010); in common carp (Cyprinus carpio) for Aegle marmelos (Pratheepa et al. 2010).

Lysozyme is a fish defence element, which causes lysis of bacteria and activation of the complement system and phagocytes by acting as opsonin (Magnadottir 2006). Christybapita et al. (2007) was reported that enhanced serum lyzozim activity in Oreochromis mossambicus of Eclipta alba leaf extracts. Baba et al. (2014) also mentioned that the lysozyme activity of Sparus aurata serum wellenhanced after applying of i.p. injection of $M$. comosum plant extract. Similar elevated lysozyme activity in Oreochromis mossambicus serum was reported to acetone extract $(1 \% \mathrm{w} / \mathrm{w})$ from four medicinal plants (Bermuda grass, Cynodon dactylon; beal Aegle marmelos; winter cherry, Withania somnifera and ginger, Zingiber officinale (Immanuel et al. 2009). In addition, Awad et al. (2013) notify that they found increased levels of lysozyme in rainbow trout serum which fed with black cumin seed oil and nettle extract. In another study (Baba et al. 2016), all concentrations of oat extract-added (Avena sativa) diet fed fish serum lysozyme activity, significantly increased in the oat extract supplemented diet fed groups at all concentrations in C. carpio. However, in the present sdudy, all the doses of $M$. comosum did not increase the lysozyme activity in rainbow trout. Differences may be due to different fish species, plant extraction method, route of administration and time used in these studies.

In the present study, the percentage of neutrophils and monocytes were significantly elevated $(\mathrm{P}<0.05)$ that resulted in a significant increase in the total leukocyte counts in $M$. comosum $(0.5 \mathrm{mg} /$ fish $)$ applied fish. Similarly, Baba et al. (2014) also noted increased total leukocyte count, neutrophils and monocytes in Sparus aurata applied with $M$. comosum plant extract. In the other earlier study, the lymphocyte counts and total leukocyte counts also increased in Oreochromis niloticus given Echinacea purpurea supplemented diet with for 1 and 2 months feding period (Aly and Mohamed 2010).

In conclusion, $M$. comosum geophye plant extract which was given i.p. route into fish, improved and enhanced some of the nonspecific immune defense in rainbow trout. $M$. comosum could be suggested to be used for rainbow trout culture to strengthen the nonspecific immune system of fish. Thus, if it will be applied before outbreaks of disease, high numbers of mortalities might be avoided. Also, there is a need to further studies especially on the long-term feeding trials to determine the immunostimulant effects of this geophyte plant extract.

\section{Acknowledgements}

This work is a part of the research project number 104V126 financially supported by The Scientific and Technological Research Council of Turkey (TUBITAK). This study was prensented in EAFP 2007 in Grado, Italy as oral presentation.

\section{References}

Aly SM, Mohamed MF. 2010. Echinacea purpurea and Allium sativum as immunostimulants in fish culture using Nile tilapia (Oreochromis niloticus). J Anim Physiol Anim Nutr (Berl). 94 (5), e31-e39 doi: 10.1111/j.1439-0396.2009.00971.x

Anderson DP, Moritomo T, Grooth RD. 1992. Neutrophile, glass-adherent, nitroblue tetrazolium assay gives early indication of immunization effectiveness in rainbow trout. Vet. Immunol.Immunopathol.30(4):419-429. doi:10.1016/0165-2427(92)90110-C

Awad E, Awaad A. 2017. Role of medicinal plants on growth performance and immune status in fish. Fish Shellfish Immunol. 67(1):40-54.

doi: 10.1016/j.fsi.2017.05.034

Awad E, Austin D, Lyndon AR. 2013. Effect of black cumin seed oil (Nigella sativa) and nettle extract (Quercetin) on enhancement of immunity in rainbow trout, Oncorhynchus mykiss (Walbaum). Aquaculture 388-391(1):193-197 doi: 10.1016/j.aquaculture.2013.01.008

Baba E, Acar Ü, Öntaş C, Kesbiç OS, Yilmaz S. 2016. The use of Avena sativa extract against Aeromonas hydrophila and its effect on growth performance, hematological and immunological parameters in common carp (Cyprinus carpio). Ital. J. Anim. Sci. 15 (2): 325-333. doi: 10.1080/1828051X.2016.1185977

Baba E, Uluköy G, Mammadov R. 2014. Effects of Muscari comosum Extract on Nonspecific Immune 
Parameters in Gilthead Seabream, Sparus aurata (L. 1758). J World Aquacult. Soc. 45 (2): 173-182 doi: 10.1111/jwas. 12100

Christybapita D, Divyagnaneswari M, Michael RD. 2007. Oral administration of Eclipta alba leaf aqueous extract enhances the non-specific immune responses and disease resistance of Oreochromis mossambicus. Fish Shellfish Immunol. 23(4):840-852 doi: 10.1016/j.fsi.2007.03.010

Deivasigamani B, Subramanian V. 2016. Applications of Immunostimulants in Aquaculture: A Review. Int. J. Curr. Microbiol. App. Sci. 5(9): 447-453. doi: 10.20546/ijcmas.2016.509.048

Dügenci SK, Arda N, Candan A. 2003. Some medicinal plants as immunostimulant for fish. J Ethnopharmacol.88 (1), 99-106 doi: 10.1016/S0378-8741(03)00182-X

Engstad RE, Robertsen B, Frivold E. 1992. Yeast glucan induces increase in lysozyme and complementmediated haemolytic activity in Atlantic salmon blood. Fish Shellfish Immunol. 2 (4): 287-297 doi: 10.1016/S1050-4648(06)80033-1

Immanue G, Uma RP, Iyapparaj P, Citarasu T, Punitha Peter SM, Michael Babu M, Palavesam A. 2009. Dietary medicinal plant extracts improve growth, immune activity and survival of tilapia Oreochromis mossambicus. J Fish Biol 74 (7): 1462-1475 doi: 10.1111/j.1095-8649.2009.02212.x

Lee TH, Qiu F, Waller GR, Chou CH. 2000. Three new flavonol galloylglycosides from leaves of Acacia confusa. J. Nat. Prod. 63(5): 710-712 doi: 10.1021/np990482w

Logambal SM, Venkatalakshmi S, Michael RD. 2000. Immunostimulatory effect of leaf extract of Ocimum sanctum Linn. in Oreochromis mossambicus (Peters). Hydrobiologia, 430 (1-3):113-120. doi: 10.1023/A:1004029332114

Loizzo MR, Tundis R, Menichini F. 2010. Chelating, antioxidant and hypoglycaemic potential of Muscari comosum (L.) Mill. bulb extracts. Int J Food Sci Nutr. 61(8):780-791. doi: $10.3109 / 09637486.2010 .482521$

Magnadottir B. 2006. Innate immunity of fish (Overview). Fish Shellfish Immunol. 20 (2): 137-151. doi: 10.1016/j.fsi.2004.09.006

Mehana EE, Rahmani AH, Aly SM. 2015. Immunostimulants and Fish Culture: An Overview. Annu Res Rev Biol. 5 (6):477-489 doi: $10.9734 / A R R B / 2015 / 9558$

Nasrabadi, M, Halimi M, Nadaf M. 2013. Phytochemical screening and chemical composition of extract of
Muscari neglectum. Middle-East J Sci Res 14(4):566569.

doi: 10.5829/idosi.mejsr.2013.14.4.71191

Pieroni, A, Janiak V, Durr CM, Ludeke S, Trachsel E, Heinrich M. 2002. In vitro antioxidant activity of noncultivated vegetables of ethnic Albanians in southern Italy. Phytother. Res. 16 (5):467-473. doi: $10.1002 /$ ptr. 1243

Plumb, J. A., and Hanson, LA. 2011. Health Maintenance and Principal Microbial Diseases of Cultured Fishes. Hoboken, NJ: Wiley-Blackwell. doi: 10.1002/9780470958353

Pratheepa V, Ramesh S, Sukumaran N. 2010. Immunomodulatory effect of Aegle marmelos leaf extract on freshwater fish Cyprinus carpio infected by bacterial pathogen Aeromonas hydrophila. Pharm. Biol.48 (11): 1224-1239 doi: $10.3109 / 13880201003713598$

Schaperclaus W, Kulow H, Schreckenbach K. (1991) Hematological and serological technique. In: Fish Disease, Vol. 1,2nd edn, ed. by V.S.Kothekar), pp. 71-108. Gulab primlani, Oxonian Press, New Delhi, India.

Steinhagen D, Kruse P, Körting W. 1990. Some heamatological observations on carp, Cyprinus carpio L. experimentally infected with Trypanoplasma borreli Laveron. J Fish Dis. 13(2) :157-162 doi: 10.1111/j.1365-2761.1990.tb00768.x

Sudhakaran DS, Srirekha P, Devasree LD, Premsingh S, Michael RD. 2006. Immunostimulatory effect of Tinospora cordifolia Miers leaf extract in Oreochromis mossambicus. Indian J Exp Biol. 44 (9):726-732

Sharma A, Deo AD, Riteshkumar ST, Chanu TI, Das A. 2010. Effect of Withania somnifera (L. Dunal) root as a feed additive on immunological parameters and disease resistance to Aeromonas hydrophila in Labeo rohita (Hamilton) fingerlings. Fish Shellfish Immunol. 29 (3):508-512 doi: $10.1016 /$ j.fsi.2010.05.005

Tanker M, Tanker N. 1991. Farmakognozi Cilt 1. Ankara Universitesi, Eczacilık Fakültesi yayını, No:66, Ankara. (In Turkish) [cited 2017 November 11] Available from http://kitaplar.ankara.edu.tr/dosyalar/pdf/313.pdf

Villa F, Borgonovo G, Cappitelli F, Giussani B, Bassoli A. 2012. Sub-lethal concentrations of Muscari comosum bulb extract suppress adhesion and induce detachment of sessile yeast cells. Biofoling 28(10):1107-1117. doi: $10.1080 / 08927014.2012 .734811$ 